Sains Malaysiana 50(7)(2021): 1913-1920

http://doi.org/10.17576/jsm-2021-5007-07

\title{
Validasi Kaedah Kromatografi Cecair Berprestasi Tinggi (HPLC) Jenis Penukar Ion dan Perbandingannya terhadap HPLC Jenis Fasa Berbalik bagi Penentuan Jumlah Homosisteina
}

(Validation of Ion Exchange High Performance Liquid Chromatography (HPLC) Method and Its Comparison with

Reverse Phase HPLC for Total Homocysteine Determination)

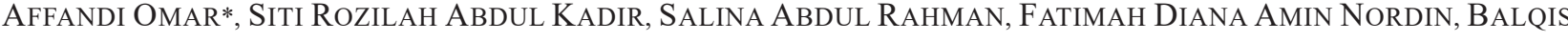 \\ Kamarudin, Nur Jannaim Muhamad, Rosnani Mohamed, Nurul Adibah Rozali, Norzahidah Khalid, \\ MUHD IRFAN BUKHARI AHMAD NAZRI \& JULAINA ABDUL JALIL
}

\begin{abstract}
ABSTRAK
Kajian ini dijalankan untuk menilai kemampuan kaedah penentuan jumlah homosisteina dalam plasma dengan menggunakan kromatografi cecair berprestasi tinggi jenis penukar ion (HPLC-IEC) dan membandingkan kaedah ini dengan kit komersil yang menggunakan kromatografi cecair berprestasi tinggi jenis fasa berbalik (HPLC-RPC). Validasi kaedah bagi penentuan jumlah homosisteina menggunakan HPLC-IEC telah dilakukan mengikut panduan yang dikeluarkan oleh Jabatan Standard Malaysia. Sebanyak 57 sampel daripada pesakit yang dihantar untuk penentuan jumlah homosisteina telah diuji secara serentak untuk menentukan korelasi antara kedua kaedah tersebut. Hasil kajian ini mendapati bahawa validasi kaedah ini telah memenuhi keperluan ISO MS 15189 dan kelinearan sehingga 500 $\mu M$ dengan pekali penentuan, $r^{2}$ ialah 0.999. Kepersisan yang dikaji pada aras normal $(10 \mu M)$ dan aras berpenyakit/ abnormal (60 $\mu \mathrm{M}$ ) bagi kebolehulangan adalah masing-masing 3.2\% dan 3.8\% manakala bagi kebolehasilan semula masing-masing adalah $8.0 \%$ dan $8.3 \%$. Had pengesanan dan had pengiraan yang diperoleh adalah 0.9274 dan $3.0912 \mu$ M. Keputusan ketepatan bagi kembalian semula adalah 92\% dan bias adalah -8.6\%. Perbandingan kaedah yang telah divalidasi dengan kit komersil menunjukkan hubungan korelasi yang kuat antara kedua-dua kaedah ini (y= $0.721 x+4.034 ; r=0.978 ; p<0.05)$. Oleh yang demikian, kaedah penentuan jumlah homosisteina menggunakan HPLCIEC menunjukkan kepersisan yang memuaskan dan korelasi yang kuat setara dengan kit komersil yang dianalisis menggunakan HPLC-RPC. Kaedah ini lebih menjimatkan kos reagen dan mampu menganalisis lebih banyak sampel jika dibandingkan dengan kit komersil. Ini sekaligus dapat membantu dalam diagnosis bagi penyakit kepincangan metabolisme terwaris (IEM) terutama dalam metabolisme homosisteina dengan tepat.
\end{abstract}

Kata kunci: Jumlah homosisteina; kromatografi cecair berprestasi tinggi; validasi kaedah

\section{ABSTRACT}

The aim of this study was to validate the performance of plasma total homocysteine method using high performance of liquid chromatography ion exchange column (HPLC-IEC) and to compare this method with a commercially available kit analyzed using HPLC reverse phase column. Method validation was performed according to the Standards Malaysia Guidelines. Correlation study was done simultaneously between both methods using patients' samples ( $n=$ 57) sent for total homocysteine determination. This study found that the HPLC-IEC method validation has met the MS ISO 15189 requirement criteria with linearity up to $500 \mu M$ (coefficient of determination, $r^{2}=0.999$ ). Precision was studied on normal $(10 \mu \mathrm{M})$ and abnormal $(60 \mu \mathrm{M})$ level, with 3.2 and $3.8 \%$ for repeatability and 8.0 and $8.3 \%$ for reproducibility. The limit of detection and quantitation were 0.9274 and $3.0912 \mu M$. As for accuracy, the results for recovery and bias were 92 and $-8.6 \%$. Method comparison showed a strong correlation between both methods $(y=0.721 x$ $+4.034 ; r=0.978 ; p<0.05)$. In conclusion, total homocysteine method using HPLC-IEC showed acceptable precision with strong correlation with commercial kit analyzed using HPLC-RPC. This method is more economical compared with commercial kit and it helps to diagnose inborn errors of metabolism (IEM) disorders especially in homocysteine metabolism accurately.

Keywords: High performance liquid chromatography; method validation; total homocysteine 


\section{PENGENALAN}

Homosisteina merupakan asid amino yang mengandungi sulfur dan mempunyai berat molekul sebanyak 135.2 dalton. Ia merupakan asid amino perantara yang mempunyai peranan penting dalam proses metabolisme tubuh manusia. Jumlah homosisteina terdiri daripada homosisteina bebas, homosistina (gabungan dua molekul homosisteina) dan homosisteina-terikat protein. Hampir $70 \%$ daripada jumlah homosisteina terdiri daripada homosisteina yang terikat dengan protein terutamanya albumin. Namun, terdapat kurang 1\% daripadanya yang terdiri daripada homosisteina bebas (Wada et al. 2018; Wiley et al. 1988).

Peningkatan paras homosisteina dalam darah adalah disebabkan oleh kekurangan vitamin B12, vitamin B6 dan asid folik (Carey et al. 1966; Wada et al. 2018), ataupun berpunca daripada penyakit kepincangan metabolisme terwaris (IEM) terutama kekurangan atau ketiadaan enzim-enzim yang terlibat di dalam kitaran metabolisme homosisteina seperti enzim cysthathionine $\beta$-synthase (CBS), methionine synthase (MS), methylene tetrahydrofolate reductase (MTHFR) dan $\gamma$-cystathionase (Gaull 1972). Peningkatan paras homosisteina ini dapat dikesan dalam sampel darah dan air kencing. Antara simptom yang dapat dikesan akibat peningkatan paras homosisteina adalah seperti terencat akal, sawan, sindrom seakan Marfan, kehilangan jisim tulang dan masalah pergerakan.

Sehingga kini di Malaysia, ujian diagnostik untuk jumlah homosisteina hanya terdapat di Institut Penyelidikan Perubatan (IMR) yang menggunakan alatan kromatografi cecair berprestasi tinggi jenis fasa berbalik (HPLC-RPC) (KKM 2013). Walau bagaimanapun, reagen yang digunakan agak mahal dan keupayaan memproses sampel adalah terhad.

Pada masa sekarang, HPLC jenis penukar ion (HPLCIEC) yang digunakan di IMR adalah untuk penentuan asid amino bebas. Oleh kerana kandungan homosisteina dalam jumlah homosisteina majoritinya terdiri daripada homosisteina terikat dengan protein, penentuan jumlah homosisteina tidak dapat dilakukan dengan menggunakan HPLC-IEC ini. Ini telah mendorong kepada pengenalan kaedah baru supaya jumlah homosisteina dapat ditentukan dengan menggunakan HPLC-IEC. Oleh yang demikian, proses validasi kaedah perlu dilakukan bagi kaedah baru sebelum pengujian kepada sampel pesakit. Ini merupakan syarat wajib yang perlu dipatuhi bagi memenuhi keperluan akreditasi ISO MS 15189 (JSM 2014).
Dalam penyelidikan ini, kajian validasi kaedah telah dijalankan bagi penentuan jumlah homosisteina di dalam plasma dengan menggunakan HPLC-IEC dan membandingkan kaedah ini terhadap kit komersil yang dianalisis melalui HPLC-RPC. Berdasarkan carian kajian lepas, ini merupakan kertas saintifik pertama yang menerangkan proses validasi kaedah dalam Bahasa Melayu.

\section{BAHAN DAN KAEDAH}

\section{BAHAN KIMIA DAN PERALATAN}

Bahan kimia yang digunakan bagi kaedah ini dibeli daripada Sigma Aldrich kecuali dinyatakan sebaliknya iaitu asid sulfosalisalik (SSA) (Winsconsin, Amerika Syarikat); bahan-bahan piawai seperti homosisteina (Steinheim, Jerman); valina, metionina dan norvalina (Missouri, Amerika Syarikat); serta dithioerithritol (Missouri, Amerika Syarikat). Larutan penimbal litium sitrat $\mathrm{pH} 3.15$ dan $\mathrm{pH}$ 3.50; larutan penimbal litium hidroksida dan larutan ninhidrin diperoleh daripada Biochrom Ltd (Cambridge, UK). Peralatan dan radas yang digunakan adalah instrumen HPLC-IEC (Biochrom 30) (Cambridge, UK); bahan fasa pegun penukar ion bersaiz $20 \mathrm{~cm} \times 4.6 \mathrm{~mm}$; penuras bersaiz $0.22 \mu$; tiub mini dan vial.

\section{SAMPEL}

Sampel untuk validasi kaedah terdiri daripada kawalan kualiti aras berpenyakit/abnormal yang dibeli daripada Stichting Kwaliteitsbewaking Medische Laboratoriumdiagnostiek (SKML, Belanda). Bagi aras normal, sampel plasma terkumpul disediakan dengan tujuh sampel plasma daripada individu normal yang berbeza. Plasma terkumpul ini disebatikan selama 4-6 jam sebelum diagihkan kepada tiub kecil yang berisi padu 200$300 \mu \mathrm{L}$ dan disimpan di dalam peti sejuk beku bersuhu -30 ${ }^{\circ} \mathrm{C}$. Selain itu, sebanyak 57 sampel pesakit telah digunakan dalam kajian perbandingan kaedah bagi penentuan jumlah homosisteina.

\section{PENYEDIAAN SAMPEL}

Sebanyak $20 \mu \mathrm{L}$ ditioerithritol (DTE) ditambahkan ke dalam $200 \mu \mathrm{L}$ sampel plasma dan dieram selama 5 minit pada suhu bilik. Kemudian, $100 \mu \mathrm{L} 10 \%$ SSA ditambah kepada campuran tersebut dan dieram selama 30 minit pada suhu $4{ }^{\circ} \mathrm{C}$ dan seterusnya diempar pada kelajuan 10,000 rpm selama 5 minit. Supernatan dipindahkan ke 
dalam tiub khas (insert) di dalam vial untuk dianalisis menggunakan alatan HPLC-IEC. Sampel akan disuntik ke dalam fasa pegun yang mengandungi resin penukar ion. Seterusnya analit ini bergabung dengan ninhidrin yang berfungsi sebagai agen terbitan di dalam ruangan tindak balas dan menghasilkan sebatian warna yang akan dikesan oleh pengesan pada jarak gelombang $570 \mathrm{~nm}$. Untuk kit komersil jumlah homosisteina, penyediaan sampel adalah mengikut panduan pengeluar (BioRad Laboratories, Munich, Jerman).

\section{INSTRUMENTASI}

\section{Kaedah HPLC-IEC}

HPLC-IEC model Biochrom 30 Amino Acid Analyser dengan pengesan jenis penyerapan diperoleh daripada Biochrom Ltd (Cambridge, UK). Masa analisis ialah 24 minit bagi setiap suntikan. Program elutan telah dioptimumkan dengan menggunakan penimbal litium sitrat $0.5 \mathrm{M}, \mathrm{pH} 3.15$ dan litium sitrat $0.9 \mathrm{M}, \mathrm{pH} 3.5$ dengan suhu $65^{\circ} \mathrm{C}$. Selepas tindak balas dengan larutan ninhidrin (suhu $75^{\circ} \mathrm{C}$ ), asid amino yang berkenaan akan dikesan pada jarak gelombang $570 \mathrm{~nm}$. Dalam keadaan ini, jumlah homosisteina akan terelut pada 14.5 minit dan metionina pada 15.7 minit. Ini membolehkan 48 sampel dapat dianalisis secara automatik dalam masa 24 jam. Data yang diperoleh akan dianalisis dengan menggunakan perisian EZchrome Elite (versi 2.8).

\section{Kaedah HPLC-RPC}

HPLC-RPC model Agilent 1200 dengan pengesan jenis pendarfluour diperoleh daripada Agilent Technologies (Jerman). Masa analisis ialah 5 minit bagi setiap suntikan. Program elutan yang dipilih adalah seperti yang disyorkan oleh pengeluar kit. Secara ringkasnya, program elutan telah dioptimumkan dengan menggunakan penimbal metanol dengan aliran $0.7 \mathrm{~mL} /$ minit dan suhu $45^{\circ} \mathrm{C}$. Sebatian homosisteina dengan bahan berpendafluour, 4-(aminosulfonil)-7-fluorobenzo-2-oksa-1,3-diazole yang telah dilakukan langkah pra-fasa pegun akan dikesan dengan jarak gelombang $385 \mathrm{~nm}$ (pengujaan) dan 515 $\mathrm{nm}$ (pemancaran). Analit homosisteina akan terelut pada 3.0 minit. Data yang diperoleh akan dianalisis dengan menggunakan perisian Agilent Chemstation (versi B.2.01)

\section{VALIDASI KAEDAH}

\section{Kelinearan}

Bahan piawai homosisteina dicairkan menjadi beberapa cairan bersiri iaitu 500, 250, 125, 62.5, 31.25, 15.625, 7.813, 3.91 dan 1.95 di dalam unit $\mu \mathrm{mol} / \mathrm{L}$. Setiap kepekatan ini disuntik ke dalam HPLC-IEC untuk ditentukan kawasan di bawah lengkok.

\section{Kepersisan}

Kepersisan terbahagi kepada dua iaitu kebolehulangan dan kebolehasilan semula. Terdapat dua aras plasma daripada kawalan kualiti yang digunakan iaitu aras normal dan aras abnormal. Bagi uji kaji kebolehulangan, sampel diproses $(n=5)$ bagi setiap aras dan dijalankan serentak dalam masa yang sama. Bagi uji kaji kebolehasilan semula, sampel juga diproses $(n=1)$ bagi setiap aras namun dijalankan sebanyak satu kali untuk lima hari berturutan.

\section{Had Pengesanan dan Had Pengiraan}

Untuk uji kaji ini, bahan piawai homosisteina dicairkan kepada kepekatan terendah $(1.95 \mu \mathrm{mol} / \mathrm{L})$ sebelum ditambahkan ke dalam penimbal muatan. Sampel ini dianalisis sebanyak 10 kali.

\section{Ketepatan}

Kajian ketepatan mempunyai dua komponen iaitu bias dan kembalian semula. Bias dihitung berdasarkan kepada uji kaji kelinearan. Bagi parameter kembalian semula pula, bahan piawai yang berkepekatan asal iaitu $2500 \mu \mathrm{mol} / \mathrm{L}$ dicairkan menjadi kepekatan yang dikehendaki iaitu $50 \mu \mathrm{mol} / \mathrm{L}$. Sebanyak $100 \mu \mathrm{L}$ larutan kepekatan yang telah dicairkan itu ditambah kepada 100 $\mu \mathrm{L}$ sampel plasma terkumpul sebelum dilakukan analisis jumlah homosisteina $(n=6)$. Sampel ini dikenali sebagai sampel yang ditambah. Analisis jumlah homosisteina juga dilakukan ke atas sampel plasma terkumpul yang tidak ditambah bahan piawai ke dalamnya dan sampel ini dikenali sebagai sampel yang tidak ditambah $(n=6)$.

\section{PEMBANGUNAN KAEDAH}

Dua uji kaji pembangunan kaedah telah dilakukan menggunakan HPLC-IEC iaitu untuk menentukan kadar aliran yang optimum bagi mendapatkan puncak yang simetri dan pemisahan antara analit yang sempurna, dan untuk menentukan isipadu penggunaan sampel yang cekap.

Bagi uji kaji pertama, bahan piawai homosisteina (n $=10$ ) disuntik ke dalam HPLC-IEC dan dianalisis dengan menggunakan enam kadar aliran berbeza iaitu $0.5 \mathrm{~mL} /$ minit, $0.6,0.7,0.8,0.9$ dan $1.0 \mathrm{~mL} /$ minit. Untuk uji kaji kedua pula, sampel biologi daripada pesakit dan kawalan kualiti $(n=27)$ telah diproses dan dianalisis dengan menggunakan kedua-dua isipadu iaitu $200 \mu \mathrm{L}$ (isipadu 
asal) dan $50 \mu \mathrm{L}$ (isipadu baru) mengikut kadar aliran yang ditetapkan iaitu $0.5 \mathrm{~mL} / \mathrm{minit}$.

\section{PERBANDINGAN KAEDAH}

Sebanyak 57 sampel yang telah diketahui kepekatannya (dibahagikan kepada tiga kumpulan iaitu nilai yang normal, pertengahan dan berpenyakit) ditentukan serentak dengan analisis jumlah homosisteina menggunakan kedua-dua kaedah iaitu analisis HPLC-IEC yang menggunakan protokol yang telah dioptimumkan dan analisis menggunakan kit komersil oleh instrumen HPLCRPC.

\section{UJIAN STATISTIK}

Bagi kajian kelinearan, graf kelinearan kawasan di bawah lengkok melawan kepekatan piawai dibentuk bagi mendapatkan nilai pemalar kelinearan. Bacaan min bagi kepersisan kebolehulangan dan kepersisan kebolehasilan semula ditunjukkan sebagai pekali variasi yang dihitung sebagai peratusan sisihan piawai kepada bacaan min. Bagi peratusan kembalian semula, keputusan dihitung melalui peratusan bersih kepekatan (Min sampel yang ditambah - min sampel yang tidak ditambah) kepada anggaran kepekatan piawai yang ditambah. Pekali korelasi Pearson dan ujian regresi linear digunakan dalam kajian perbandingan kaedah. Kekuatan sesuatu perhubungan antara dua kaedah yang dibandingkan dapat diukur dengan menggunakan pekali korelasi Pearson. Dalam kajian pembangunan kaedah, ujian T-berpasangan digunakan untuk mengenal pasti terdapat sama ada terdapat perbezaan signifikan antara dua kumpulan isipadu yang berbeza. Kesemua ujian statistik dianalisis dengan menggunakan perisian SPSS, versi 14 (SPSS Inc, Chicago, Amerika Syarikat). Nilai- $p$ yang kurang daripada 0.05 dianggap sebagai signifikan secara statistik.

\section{HASIL DAN PERBINCANGAN}

\section{VALIDASI KAEDAH}

Validasi kaedah merupakan suatu proses penetapan gabungan parameter analitikal yang dilakukan untuk mengesahkan bahawa kaedah tersebut mampu memenuhi kriteria dan ketetapan yang ditetapkan (NATA guideline). Validasi kaedah ini perlu apabila sesuatu makmal tersebut menggunakan kaedah yang bukan piawai atau kaedah tersebut merupakan kaedah piawai tetapi di luar bidang kaedah tersebut yang digunakan secara kebiasaannya (contoh: kaedah biasa menggunakan sampel plasma tetapi kaedah baru menggunakan sampel air kencing) atau berlaku perubahan pada kaedah piawai (contoh terdapat penambahan langkah seperti pengeraman yang tiada di dalam kaedah asal). Dalam kajian ini, validasi kaedah perlu dijalankan ke atas kaedah baru yang menggunakan HPLC-IEC kerana sebelum ini penentuan asid amino homosisteina dijalankan dengan menggunakan kaedah HPLC-RPC.

Terdapat beberapa parameter penting dalam validasi kaedah. Antaranya kelinearan, kepersisan, had pengesanan dan ketepatan. Dari segi kelinearan, didapati kepekatan larutan bahan piawai adalah linear. Ini dapat dibuktikan daripada nilai pekali penentuan, $\mathrm{r}^{2}$ adalah 0.999 (Rajah 1). Ini bermakna keputusan ujian yang diperoleh adalah berkadaran dengan kepekatan analit bahan piawai tersebut.

Kepersisan pula boleh dilihat dari segi faktor kebolehulangan dan kebolehasilan semula. Secara keseluruhannya, kepersisan bagi kedua-dua faktor ini adalah memuaskan dengan nilai pekali variasi $(\% \mathrm{CV})$ bagi kedua-dua faktor adalah di bawah $10 \%$ (Jadual 1). Bagi uji kaji untuk menentukan had pengesanan dan had pengiraan, keputusan yang diperoleh masingmasing adalah 0.9274 dan $3.0912 \mu \mathrm{M}$. Ketepatan diukur berdasarkan kombinasi kembalian semula dan bias. Bagi kembalian semula, nilai yang diperoleh adalah $92 \%$ dan purata bagi bias pula adalah $-8.6 \%$. Bias sebanyak $-8.6 \%$ menunjukan bahawa nilai kiraan semula bahan piawai homosisteina adalah berkurangan sebanyak $8.6 \%$ dari nilai sebenar bahan piawai tersebut. Kesemua keputusan ini memenuhi kriteria penerimaan yang telah ditetapkan (Peris-Vicente et al. 2015).

Berdasarkan keputusan kajian yang diperoleh, secara keseluruhannya kaedah penentuan jumlah homosisteina menggunakan HPLC-IEC telah berjaya divalidasi berdasarkan garis panduan yang dikeluarkan oleh badan akreditasi yang diiktiraf seperti NATA (2018). Oleh itu, kajian ini telah menunjukkan bahawa kaedah penentuan jumlah homosisteina yang menggunakan HPLC-IEC boleh dijadikan pilihan untuk dijalankan di makmal hospital yang mempunyai instrumen tersebut. Keputusan kepersisan dalam kajian ini juga sebanding dengan yang telah dilaporkan oleh para penyelidik lain (Concención-Alvarez et al. 2016; Donnelly \& Pronovost 2000; Mourvaki et al. 2005; Pernet et al. 2005). 
JADUAL 1. Keputusan kepersisan bagi penentuan jumlah homosisteina

\begin{tabular}{|c|c|c|c|c|}
\hline \multirow[t]{2}{*}{ Kepersisan } & \multicolumn{2}{|c|}{ Kebolehulangan } & \multicolumn{2}{|c|}{ Kebolehasilan semula } \\
\hline & $\operatorname{Min} \pm$ Sisihan piawai & Pekali variasi (\%) & $\operatorname{Min} \pm$ Sisihan piawai & Pekali variasi (\%) \\
\hline Aras normal & $9.7 \pm 2.158$ & 3.178 & $9.66 \pm 0.773$ & 8.005 \\
\hline Aras abnormal & $56.16 \pm 2.158$ & 3.843 & $57.52 \pm 4.796$ & 8.337 \\
\hline
\end{tabular}

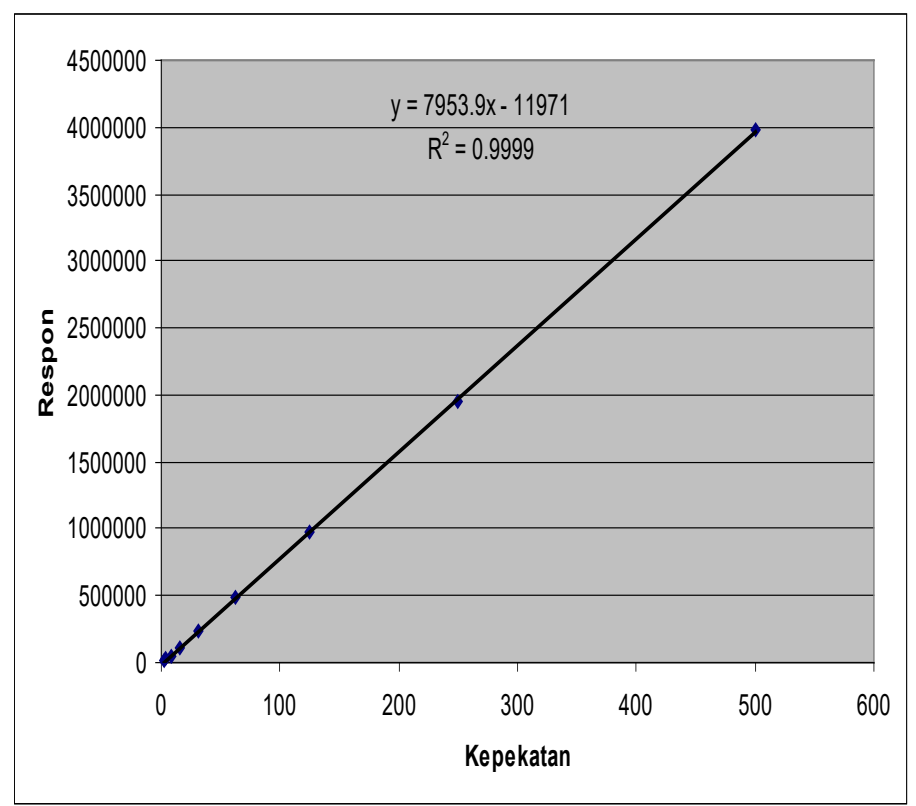

RAJAH 1. Graf kelinearan menunjukkan hubungan kepekatan bahan piawai homosisteina $(\mu \mathrm{M})$ dan respons yang merujuk kepada kawasan di bawah lengkok (mAU)

\section{KAJIAN PEMBANGUNAN KAEDAH}

Kadar aliran adalah penting dalam pemisahan analit dalam jumlah homosisteina kerana ia akan menentukan ketinggian dan pemisahan yang sempurna bagi setiap analit. Beberapa kadar aliran yang berbeza telah digunakan dalam program bagi penentuan jumlah homosisteina dengan menggunakan HPLC-IEC. Berdasarkan keputusan uji kaji, didapati pada kadar aliran 0.5 dan $0.8 \mathrm{~mL} / \mathrm{minit}$, 
ketinggian puncak bagi setiap analit adalah simetri dan pemisahannya juga sempurna. Oleh kerana tiada perbezaan signifikan antara kedua-dua kadar aliran $(p>0.05)$, kadar aliran $0.5 \mathrm{~mL} / \mathrm{minit}$ dipilih sebagai kadar aliran optimum. Ini kerana kadar aliran $0.5 \mathrm{~mL} /$ minit hanya memerlukan penggunaan reagen yang sedikit berbanding kadar aliran yang lain. Perkara ini juga dipersetujui oleh penyelidik yang lain (Lolia \& Bee 2010; Vinukonda 2008).

Bagi kajian pembangunan kaedah perbandingan di antara isipadu 200 atau $50 \mu \mathrm{L}$ pula, didapati tiada perbezaan yang signifikan diperoleh antara isipadu ini $(p>0.05)$. Ini bermakna kedua-dua isipadu memberikan keputusan yang sama tanpa mengubah diagnosis penyakit. Isipadu $50 \mu \mathrm{L}$ adalah sesuai digunakan untuk sampel daripada bayi atau kanak-kanak.

\section{KAJIAN PERBANDINGAN KAEDAH}

Dalam kajian perbandingan kaedah, keputusan yang diperoleh mendapati bahawa pekali korelasi Pearson, r bagi kedua-dua kaedah ialah 0.978. Ini menunjukkan terdapat satu hubungan yang kuat antara kaedah penentuan jumlah homosisteina yang menggunakan HPLC-RPC dengan HPLC-IEC. Selain daripada itu, nilai pekali penentuan, $\mathrm{r}^{2}$ sebanyak 0.98 menunjukkan hampir $98 \%$ daripada keputusan yang diberikan oleh HPLC-IEC adalah sama dengan keputusan yang diberikan oleh HPLCRPC. Ini dapat disimpulkan melalui persamaan regresi linear Deming bagi data ini iaitu y (keputusan HPLC-IEC) $=0.721$ (keputusan HPLC-RPC) + $4.034(p<0.05)$.
Kekuatan kajian ini terletak pada proses validasi yang menggunakan HPLC-IEC itu sendiri. Sebelum ini, HPLC-IEC digunakan untuk penentuan asid amino namun validasi kaedah penentuan jumlah homosisteina tidak pernah dijalankan. Hasil daripada kajian ini mendapati, kaedah penentuan jumlah homosisteina menggunakan HPLC-IEC adalah setanding dengan kaedah penentuan jumlah homosisteina yang menggunakan HPLC-RPC (Rajah 2).

Melalui penemuan ini, makmal yang mempunyai HPLC-IEC ini boleh melakukan analisis jumlah homosisteina dengan menggunakan reagen dan peralatan sedia ada tanpa perlu melakukan pembelian baru. Ini sekaligus dapat mengurangkan beban kewangan dengan kos untuk pembelian kit komersil dapat dikurangkan dan lebih banyak sampel dapat dianalisis dengan menggunakan HPLC-IEC ini. Hasil daripada keputusan validasi ini juga membuktikan kaedah penentuan jumlah homosisteina menggunakan HPLC-IEC ini layak untuk digunakan serta berupaya memberikan keputusan ujian secara tepat dan boleh dipercayai (Theodorsson \& Magnusson 2017).

Malah, jumlah homosisteina tidak hanya terhad kepada diagnosis penyakit IEM malah dilihat mempunyai potensi sebagai biopenanda kepada penyakit Alzheimer (Farina et al. 2017), pembentukan kanser (Zhang et al. 2015), kanser payudara (Pooja et al. 2015), kanser prostat (Qu et al. 2016), penyakit psoriasis (Garg et al. 2019), penyakit kencing manis sewaktu mengandung (shi et al. 2016) dan strok berulang dan strok kecil (Shi et al. 2018).

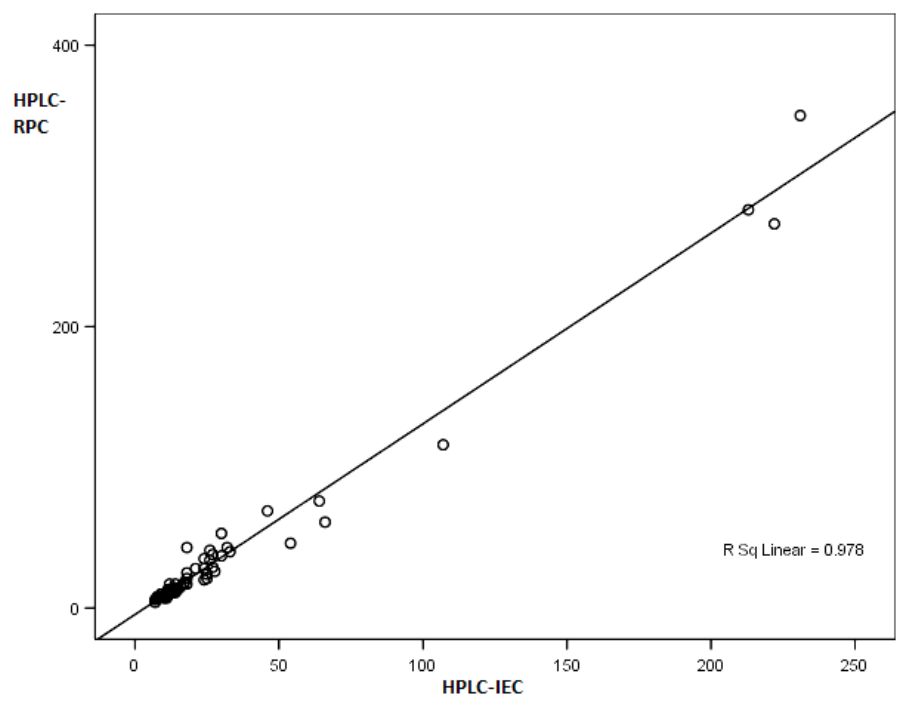

RAJAH 2. Korelasi linear antara HPLC-IEC (paksi-x) dan HPLC-RPC (paksi-y) bagi penentuan jumlah homosisteina $(p<0.05)$ 


\section{KESIMPULAN}

Kaedah penentuan jumlah homosisteina menggunakan HPLC-IEC telah berjaya divalidasi dan keputusannya adalah sebanding dengan kaedah jumlah homosisteina menggunakan kit komersil dan HPLC-RPC.

\section{PENGHARGAAN}

Penghargaan ditujukan kepada Ketua Pengarah Kesihatan Malaysia, Kementerian Kesihatan Malaysia kerana memberi kebenaran untuk menerbitkan kertas penulisan saintifik ini. Pengarang juga ingin merakamkan penghargaan kepada kakitangan makmal Unit Biokimia, Pusat Diagnostik Khas atas pengurusan sampel dan penyediaan bahan kimia. Affandi Omar dan Julaina Abdul Jalil merancang penyelidikan, melakukan analisis statistik dan merangka manuskrip. Siti Rozilah Abdul Kadir melakukan kerja makmal, menganalisis data dan kajian perpustakaan. Salina Abdul Rahman, Fatimah Diana Amin Nordin dan Balqis Kamarudin menganalisis data bagi kajian perbandingan kaedah dan menulis manuskrip. Nur Jannaim Muhamad dan Rosnani Mohamed menganalisis data bagi kajian had pengesanan dan had pengiraan serta menulis manuskrip. Nurul Adibah Rozali, Norzahidah Khalid dan Muhd Irfan Bukhari Ahmad Nazri menganalisis data bagi kajian kelinearan, kepersisan dan ketepatan serta menulis manuskrip. Kesemua pengarang telah memberi sumbangan yang sama dalam penghasilan manuskrip ini.

\section{RUJUKAN}

Carey, M.C., Fennelly, J.J. \& FitzGerald, O. 1966. Folate metabolism in homocystinuria. Ir. J. Med. Sci. 41(11): 488492.

Concención-Alvarez, A., Camayd-Viera, I. \& Nuevas-Paz, L. 2016. Validation of an HPLC method for total homocysteine quantification in plasma. Rev. Lab. Clin. 9(2): 40-47.

Donnelly, J.G. \& Pronovost, C. 2000. Evaluation of the Abbott IMxTM fluorescence polarization immunoassay and the Bio-Rad enzyme immunoassay for homocysteine: Comparison with high-performance liquid chromatography. Ann. Clin. Biochem. 37(2): 194-198.

Farina, N., Jernerén, F., Turner, C., Hart, K. \& Tabet, N. 2017. Homocysteine concentrations in the cognitive progression of Alzheimer's disease. Exp. Gerontol. 99: 146-150.

Garg, P., Gupta, S., Gupta, N. \& Gupta, N. 2019. Homocysteine, a biomarker of cardiovascular diseases, in psoriasis - a case control study. Clin. Dermatol. J. 4(1): 000171.

Gaull, G.E. 1972. Homocystinuria, Vitamin B6, and folate metabolic interrelationships and clinical significance. $J$. Pediatr. 81(5): 1014-1018.
Gong, T., Wang, J., Yang, M., Shao, Y., Liu, J., Wu, Q., Xu, Q., Wang, H., He, X., Chen, Y., Xu, R. \& Wang, Y. 2016. Serum homocysteine level and gestational diabetes mellitus: A meta-analysis. J. Diabetes Investig. 7(4): 622-628.

JSM. 2014. MS ISO 15189: Medical Laboratories - Requirements for Quality and Competence. Jabatan Standard Malaysia (JSM).

KKM. 2013. Annual Report Ministry of Health. Kementerian Kesihatan Malaysia (KKM).

Lolia, A. \& Bee, S. 2010. Rapid analysis of homocysteine levels. Biochrom Ltd Application Note: B30.5.

Mourvaki, E., Ferrante, F., Ghirarduzzi, A., Brini, M., Depunzio, I. \& Iorio, A. 2005. Performance comparison of three assay methods used in fasting and postmethionine load plasma homocysteine determinations from patients with vascular disease. Am. J. of Clin. Pathology 124: 675-681.

NATA. 2018. General Accreditation Guidance - Validation and Verification of Quantitative and Qualitative Test Methods. National Association of Testing Authorities (NATA).

Peris-Vicente, J., Esteve-Romero, J. \& Carda-Broch, S. 2015. Validation of analytical methods based on chromatographic techniques: An overview. Anal. Sep. Sci. 5: 1757-1808.

Pernet, P., Cuzon, G., Lim, S-K., Labau, N., Laghzal, A. \& Vaubourdolle, M. 2005. Plasma homocysteine measurement with ion exchange chromatography (Jeol Aminotac 500): A comparison with the Abbott IMx assay. Med. Princ. Pract. 15(2): 149-152.

Pooja, S., Carlus, J., Sekhar, D., Francis, A., Gupta, N., Konwar, R., Kumar, S., Kumar, S., Thangaraj, K. \& Rajender, S. 2015. MTHFR 677C $>$ T polymorphism and the risk of breast cancer: Evidence from an original study and pooled data for 28031 cases and 31880 controls. PLoS ONE 10(3): e0120654.

Qu, Y.Y., Zhou, S.X., Zhang, X., Zhao, R., Gu, C.Y., Chang, K., Yang, X.Q., Gan, H.L., Dai, B., Zhang, H.L., Shi, G.H., Zhu, Y., Ye, D.W. \& Zhao, J.Y. 2016. Functional variants of the 5-methyltetrahydrofolate-homocysteine methyltransferase gene significantly increase susceptibility to prostate cancer: Results from an ethnic Han Chinese population. Sci. Rep. 6: 36264 .

Shi, Z., Liu, S., Guan, Y., Zhang, M., Lu, H., Yue, W., Zhang, B., Li, M., Xue, J. \& Ji, Y. 2018. Changes in total homocysteine levels after acute stroke and recurrence of stroke. Sci. Rep. 8(1): 6993.

Theodorsson, E. \& Magnusson, B. 2017. Full method validation in clinical chemistry. Accred. Qual. Assur. 22(5): 235-246.

Vinukonda, G. 2008. Plasma homocysteine and methylenetetrahydrofolate reductase gene polymorphism in human health and disease. Int. J. Hum. Genet. 8(1-2): 171-179.

Wada, M., Nakamura, S. \& Nakashima, K. 2018. HPLC analysis of homocysteine and related compounds. In Nonproteinogenic Amino Acids, edited by Iancu, C.E. \& Filip, N. London: Intechopen. pp. 11-18. 
Wiley, V.C., Dudman, N.P. \& Wilcken, D.E.L. 1988 Interrelations between plasma free and protein-bound homocysteine and cysteine in homocystinuria. Metabolism 37(2): 191-195.

Zhang, D., Wen, X., Wu, W., Guo, Y. \& Cui, W. 2015. Elevated homocysteine level and folate deficiency associated with increased overall risk of carcinogenesis: Meta-analysis of 83 case-control studies involving 35,758 individuals. PLoS ONE 10(5): e0123423.

Affandi Omar*, Salina Abdul Rahman, Fatimah Diana Amin Nordin, Balqis Kamarudin, Nur Jannaim Muhamad, Rosnani Mohamed \& Julaina Abdul Jalil

Unit Metabolisme Terwaris

Pusat Penyelidikan Pemakanan, Metabolisme dan Kardiovaskular Institut Penyelidikan Perubatan

Kompleks Institut Kesihatan Negara

Kementerian Kesihatan Malaysia

Jalan Setia Murni U13/52, Bandar Setia Alam

40170 Shah Alam, Selangor Darul Ehsan

Malaysia
Siti Rozilah Abdul Kadir, Nurul Adibah Rozali, Norzahidah Khalid \& Muhd Irfan Bukhari Ahmad Nazri

Unit Biokimia, Pusat Diagnostik Khas

Institut Penyelidikan Perubatan

Kementerian Kesihatan Malaysia

Jalan Pahang

50588 Kuala Lumpur, Wilayah Persekutuan

Malaysia

*Pengarang untuk surat-menyurat; email: fendi.omar@moh. gov.my

Diserahkan: 25 Jun 2020

Diterima: 1 Disember 2020 